\title{
Rice Production Analysis in Reflecting Rice Self-sufficiency in Indonesia
}

\author{
Fadillah Isnaeni Fathonah $^{1, *}$ and Mashilal $^{2}$ \\ ${ }^{1}$ Department of Economics, FEB, Diponegoro University, Indonesia \\ ${ }^{2}$ Department of Islamic Economics, FEBI, UIN Walisongo, Indonesia
}

\begin{abstract}
Indonesia was the third rank after China and India as the largest rice-producing country in the world in 2020. However, data on the Indonesian import of rice shows fluctuation in recent years. Food security and self-sufficiency have been a problem faced by many countries before COVID-19 came in. Hence, this observation aims to analyze the influence of land area, labor, and farmers' capitals on rice production in reflecting rice selfsufficiency in Indonesia. This research applied panel data methodology with land area, farm laborers, and farmers' capitals as the independent variables while rice production as the dependent variable, recorded in 2018 to 2020 in 34 provinces in Indonesia. The most appropriate model for this research was the random effect model. The results confirmed that land area had a positive and significant impact while the other two variables showed no significant effects on rice production in Indonesia.
\end{abstract}

\section{Introduction}

The contribution of agricultural sectors is in the second place to the state revenue after the industrial sector in recent years. Agriculture is also able to survive and contribute to the state revenue of Indonesia during COVID-19. The growth in the value of Gross Domestic Product (GDP) reached 13.17 percent during 2020. This number increased compared to 2018 at 12.81 percent [1]. It shows that agriculture is a sector that is crucial in a country related to the provision and fulfillment of national food for the whole community.

Rice is a type of food with the highest total consumption that can beat sweet potatoes, corn, and other types of food, based on the average weekly consumption per capita of households that reached 1.5 kilos in 2019 [2]. Rice is also one of the mainstay commodities of the agriculture sector that is in the third place after China and India as the largest rice-producing countries with 70.8 million tons per year [3].

${ }^{*}$ Corresponding author: Fadillahisnaeni9a@gmail.com 
Thus, rice has a crucial meaning in food availability for the consumption patterns of the Indonesian people.

As an instrument of national food security, the rice self-sufficiency issues have become a problem encountered not only by Indonesia but also by other countries in the world. It encourages the United Nations (UN) to establish food availability as one of the main focuses in the sustainable development goals known as the SDGs30. This protection aims to end the problems of hunger, realize food security programs and improve nutrition fulfillment, and support the optimization of a sustainable agricultural sector [4].

Food self-sufficiency and food security have two different dimensions. The Indonesian Agency for Agricultural Research and Development, or IAARD, defines self-sufficiency as a government program in achieving food sovereignty and security in the country and is oriented to farmers' welfare [5]. Meanwhile, food security is access to food fulfillment, food availability, and utilization in food consumption for each population or individual in a country. National food security does not require the state to be self-sufficient through production. However, in the availability, it can be supported by import activities through trade between countries [6].

Food security index data in 2020, based on regions or districts and cities in Indonesia, showed that the food security in the western area of Indonesia had a higher index than in the eastern area [7]. The Global Food Security also released that the food safety value of Indonesia increased by 59.5 in 2020 compared to 2018 of 54.8. Meanwhile, the level of volatility in agricultural production in 2020 had reached 91.5 percent, and the missing food index was 84.6 percent [8].

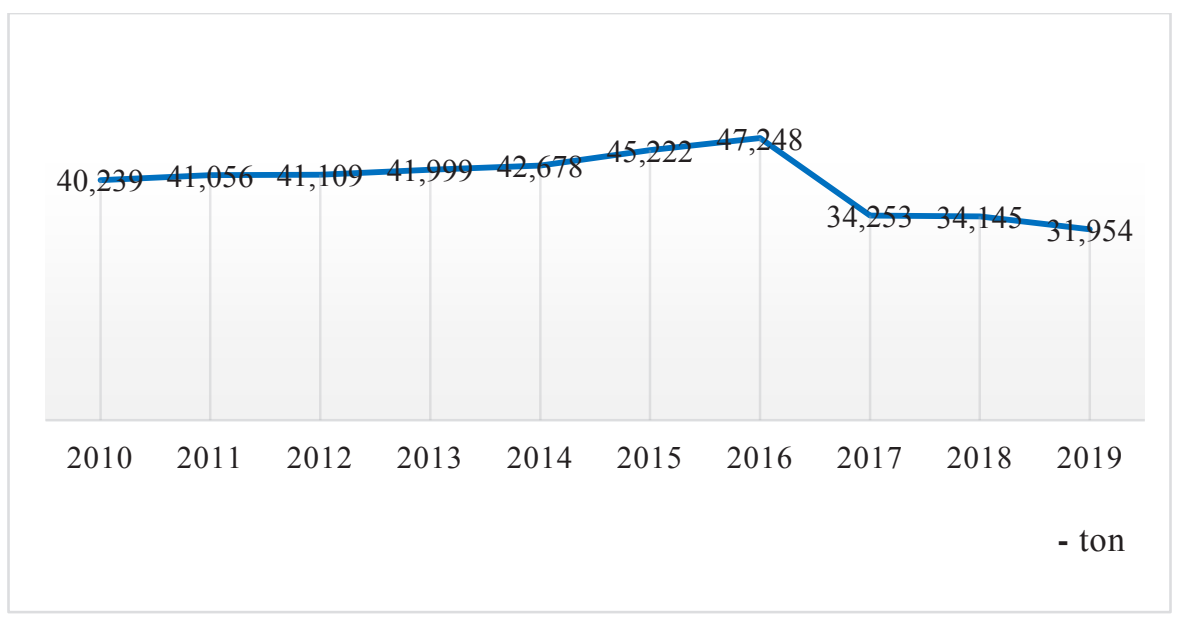

Fig. 1. The availability of rice (data taken from the Ministry of Agriculture of the Republic of Indonesia)

Figure 1 describes the fluctuation in the availability of rice in Indonesia. Rice availability in Indonesia had experienced a positive movement from 2010 until 2016, ranging from about 40-47 tons value. Meanwhile, this number decreased in recent years. In 2017 and 2018, for example, it dropped to 34\% and kept falling to 31 tons in 2019. 
Instability in domestic rice availability triggers changes in the quantity of rice imported from various countries. Rice imports of Indonesia were about 0.6 million tons in 2010, then fluctuated and decreased to 0.30 million tons in 2017 . Meanwhile, demand for rice imports increased by 2.2 million tons in 2018 and had reached 0.4 million tons in 2019 [9]. Since the country needs sufficient stock to meet domestic demand for rice and avoid a national food crisis, the government should execute the import policies. The fulfillment of food availability through higher import policies will disrupt the realization of food self-sufficiency [10]. Hence, this program does not only mean ensuring food availability in a certain period but also creating food surplus and contributing to national food security in the long-term period.

Many researchers are into these types of study to observe the actual condition of self-sufficiency and food availability in various sectors, especially in rice commodities. One of them is the study on the long-term effects of rice production on food security in the South Asian regions [11]. According to that research, Pakistan and India have proven that land availability is an indicator that can support rice production and the creation of rice self-sufficiency. Agricultural production, especially rice commodities, has an important implication in suppressing poverty and maintaining the fulfillment of the long-term food needs of the vulnerable people who lack food in South Asian countries. Meanwhile, in 2030, Iran is predicted to provide food independently by increasing irrigation efficiency in the agricultural sector, diversifying food consumption patterns, and controlling food demand scenarios. Hence, aspects of loss and waste can be overcome [12].

Another research examined the correlation of the political food chain and the transformation that occurred in rural areas to the growth of the capitalization in the agricultural sector in China [13]. The findings showed that optimization of selfsufficiency had increased capital and relations between large and profitable countries, thanks to various approaches applied to encourage grain production. The policy included incentives for grain-producing areas, grain subsidies, education on farming, and supervision for the new farm establishments. The prediction expresses that China can maintain its rice self-sufficiency until 2030 using spatial analysis and bottom-up and top-down methodologies [14]. In the meantime, there are some efforts to do, including prioritizing rice yields increase in general and optimizing the three rice-producing provinces with relatively large yield gaps. Hence, the investment return will be even higher, and China can achieve its sustainable food self-sufficiency.

There was also research conducted in African countries. The research involving eight countries in Africa showed that those countries will still be unable to generate self-sufficiency in 2025, even with the intensification of population growth and a boost in land yields [15]. Thus, regional expansion and stimulus through import policies are needed to reduce the production gap in several African countries. Another research explained the contribution of the CARD program or the Coalition for Africa Rice Development to rice production levels and the estimation of domestic rice demand and supply in sub-Saharan Africa [16]. The findings showed that CARD contributed to an increase in harvested area and increased rice yields in 2018. However, there are problems with fertilizers and irrigation that have disrupted rice production in two-thirds of SSA countries. Hence, continuous investment in modern agricultural infrastructure is needed to create rice self-sufficiency in 2030. 
In Indonesia, there was also research regarding the effect of political economy on the success of the self-sufficiency program [17]. According to that research, the role of BULOG (The Indonesia Logistics Bureau) in the policy instruments implementation in encouraging the efficiency of food self-sufficiency through social cost estimation had not performed well. Thus, it needs some improvements such as improving the agricultural infrastructure sectors, reducing the imports levels, and reviewing the government purchasing prices. There was also research to examine the progress of rice self-sufficiency in Indonesia in 2018-2045 using a dynamic system combined with six scenarios [18]. These scenarios consisted of extensification policies, post-harvest losses minimization policies, intensification policies, rice export policies, and other policies related to Indonesia's selfsufficiency, as well as a combined policy consisting of intensification, land conversion, and post-harvest losses policies. The results showed a dominant factor that affected the success rate of rice self-sufficiency in Indonesia, namely the policy on agricultural land conversion. Based on various previous empirical approaches, this paper analyzed the determinant indicator of rice production in Indonesia. Through the production indicator, it can reflect the condition of Indonesian food self-sufficiency in 2018-2021. Meanwhile, the production factors used are land area, labor, and additional capital issued by farmers in the agricultural sector.

\section{Research methods}

This paper is quantitative research with a random effect model on panel data analysis method. The concept and measurement used in this research consist of three independent variables as input, namely land area, labor, and farmers' capital. Those variables were to determine whether or not they had affected rice production in Indonesia in the last three years from 2018 until 2020. The input and output data were taken from the Statistic Indonesia publication of land area and rice production by provinces, the percentage of labor in agriculture sectors, and the cost of production and addition of capital goods index. The author used 34 provinces in Indonesia as the object of research.

\subsection{Panel regression}

The panel regression is a combination of cross-section and time-series models. It is different from the OLS technique because the panel regression has two dimensions; individual and time changing [19]. Panel analysis has two more advantages than those of only cross-section type or time-series data. First, the estimated parameter becomes more accurate than other models in the marginal effect usage of explanatory variables, observed in individuals and time. Technically, the panel model can reduce the collinearity between variables and provide higher degrees of freedom. That is why it can increase the efficiency of the model as well. Second, panel data can control the individual heterogeneity that other models cannot manage [20]. Hence, panel regression is a more favorable methodology regarding diverse variability, informative data presentation, lower collinearity between variables, and efficiency in degrees of freedom [21]. Three models in the panel analysis are the Common Effect Model (CEM), Fixed Effect Model (FEM), and Random Effect Model (REM) [22]. 


\subsubsection{Common effect method}

Known as Pooled Least Square, this model combines all data (pooled data) to obtain $\mathrm{N} \times \mathrm{T}$ measurement. The $\mathrm{N}$ indicates the number of cross-section units, and $\mathrm{T}$ indicates the number of series used in the study. This model assumes that the intercept value in each variable, the slope coefficient, and all units in the crosssection and time series, are in the same value. Thus, this model has to apply the Ordinary Least Square (OLS) technique for estimation. The pooled least square method follows what is written by as follows [23]:

$$
y_{i t}=\beta_{i}+\beta^{\prime} X_{i t}+\cdots+\beta^{\prime} X_{k i t}+\varepsilon_{i t}
$$

This model describes $\alpha_{i}$ is constant in all observations; $\alpha_{i}=\alpha$.

\subsubsection{Fixed effect method}

This method assumes that the variables in the model have an inconstant intercept value or can change depending on the time and the individuals. Therefore, the model needs to add dummy variables to explain the differences in interceptions to produce unbiased and efficient parameter estimates [24]. The Least Square Dummy Variable (LSDV) formula is as below [25]:

$$
y_{i t}=\beta^{\prime} X_{i t}+u_{i}+\varepsilon_{i t}
$$

\subsubsection{Random effect method}

In a fixed effect method, intercept value describes the changes that depend on the individuals and time. On the other hand, the random effect method can describe from the element of error. REM is a technique used when the value of these intercepts between individual and time does not correlate, and there is a random distribution of the error variants in time and unit. The Generalized Least Square (GLS) is the parameter estimation of the random method [22]. The GLS technique has fewer variables and can eliminate the heteroscedasticity problem, so the GLS does not require testing against classical assumptions. The REM method is as follows [26]:

$$
y_{i t}=\beta^{\prime} X_{i t}+\alpha_{i}+u_{t}+\varepsilon_{i t}
$$

\subsection{The best panel data model estimation}

There are three testing criteria to get the best model estimation on panel data regression, namely Chow test, Hausman test, and Lagrange test [27]:

\subsubsection{The Chow test}

The Chow test determines that either the fixed effect or the common effect model is the best model estimation. This test calculates the value of Residual Sum Square (SSR). Below is the Chow test hypothesis: 
$H_{0}: \mu_{1}=\mu_{2}=\cdots=\mu_{n}=0$, the best model for the research is common effect method

$H_{1}$ : there is at least one $\mu_{i} \neq 0$, the best model for the research is fixed effect method

In this test, the decision-making should reject $H_{0}$ when $F_{\text {count }}>F_{\text {table }}$ or $p<\alpha$ that means a fixed effect model is more appropriate to estimate the regression equation. If the correct result turns out to be a fixed effect model, a further test is required, namely the Hausman test. Meanwhile, when the correct result is the pooled least square method, the classical assumption and significant model test have been sufficient.

\subsubsection{The Hausman test}

This test is to determine whether fixed effect or the random effect model is the correct model. Below is the hypothesis of the Hausman test:

$H_{0}$ : correlation $\left(\mu_{n}, X_{i t}\right)=0$, the best model for the research is the random effect method

$H_{1}$ : correlation $\left(\mu_{n}, X_{i t}\right) \neq 0$, the best model for the research is the fixed effect method

This test has the decision-making to reject $H_{0}$ when $X_{\text {count }}^{2}>X_{\text {table }}^{2}$ or $p<\alpha$ that means the suitable model to use is the random effect method, so the Least Square Dummy Variable (LSDV) technique is needed.

\subsubsection{The Lagrange multiplier test}

When the Hausman test shows that the fixed effect chosen is not better than the random effect, it should apply the Lagrange multiplier test. This method aims to select which one is more appropriate between the common effect and the random effect model before the interpretation. The Lagrange Multiplier test (LM-test) can be seen in the Breusch-Pagan value. The criteria for this test are:

$H_{o}$ : Common effect is the best model

$H_{1}$ : Random effect is the best model

The decision is to reject $H_{0}$ when the LM-test $>$ chi-square or by looking at the Breusch-Pagan $\mathrm{p}$-value, that is $p<\alpha$ meaning that the most appropriate model to estimate the research model is the random effect model. Meanwhile, the null hypothesis is accepted when LM-test $<$ chi-square or the value of $p>\alpha$, meaning that the best model to estimate the research is the common effect model.

\subsection{Model significance Test}

Known as Goodness of fit, this test is to identify the accuracy of selected the best model. First, Simultaneous criteria (F-statistics) to measure the relationship between the independent on the dependent. Second, Partial criteria (T-statistics) can determine the effect individually on the dependent variable. Third, the coefficient of 
determination (R-squared test) to measure the ability of a model to explain its variations. It is a range of zero to one when the coefficient is close to one, so the input variables strongly describe the output.

\section{Results and discussion}

\subsection{Panel data model estimation}

Estimation is the initial stage in choosing the correct model. The three approaches in panel regression include common effect, fixed effect, and random effect model. The selection of the best model must pass the criteria of the Chow test, Hausman test, and Lagrange Multiplier test by looking at the p-value formed in the formula.

Table 1. Result of Panel Analysis.

\begin{tabular}{|l|c|c|c|c|c|c|}
\hline \multirow{2}{*}{$\begin{array}{c}\text { Measurement of } \\
\text { Variables }\end{array}$} & \multicolumn{2}{|c|}{ Common Effect } & \multicolumn{2}{c|}{ Fixed Effect } & \multicolumn{2}{c|}{ Random Effect } \\
\cline { 2 - 7 } & Coefficient & Prob. & Coefficient & Prob. & Coefficient & Prob. \\
\hline Land area & 1.04526 & 0.0000 & 0.797102 & 0.0000 & 1.036569 & 0.0000 \\
\hline Labor & -0.000213 & 0.9159 & 0.004430 & 0.2828 & 0.001115 & 0.6732 \\
\hline Farmers' Capital & 0.000608 & 0.7255 & 0.001008 & 0.0988 & 0.000591 & 0.2954 \\
\hline C & 0.906782 & 0.0005 & 3.323503 & 0.0063 & 0.894350 & 0.0005 \\
\hline R-squared & 0.991289 & & 0.999395 & & 0.974652 & \\
\hline
\end{tabular}

Table 1 explains that the estimated point of the common effect model has a relatively higher probability value (prob. $>0.05$ ) compared to the fixed effect model and the random effect model (prob.<0.05). The estimation results need further testing to get the best model used to determine the effect of variables in the research model.

\subsubsection{The criteria of the Chow test}

The Chow measurement is a criterion that aims to determine whether the fixed effect method or the common effect method is the best estimation model.

Table 2. The Output of the Chow Test.

\begin{tabular}{|l|c|c|c|}
\hline Effects Test & Statistic & d.f. & Prob. \\
\hline Cross-section F & 26.409101 & $(33.65)$ & 0.0000 \\
\hline Cross-section Chi-square & 272.111788 & 33 & 0.0000 \\
\hline
\end{tabular}

As seen in Table 2, the Chow test results show that the probability value is lesser than the significance value $(0.00<0.05)$, thus $H_{o}$ is rejected. The results suggest that fixed effect method is more appropriate to use.

\subsubsection{The criteria of the Hausman test}

The Hausman measurement is one of the criteria on panel analysis that selects the best approach between the fixed effect and random effect method. 
Table 3. The Output of the Hausman Test.

\begin{tabular}{|c|c|c|c|}
\hline Test Summary & Chi-Sq. Statistic & Chi-Sq. d.f. & Prob. \\
\hline Cross-section random & 5.347644 & 3 & 0.1480 \\
\hline
\end{tabular}

As seen in Table 3, the result of this test shows that the probability value is greater than the significance value $(0.1480>0.05)$, then $H_{o}$ is accepted. The result also confirms that the random effect model is more appropriate to use.

\subsubsection{The criteria of the Lagrange multiplier test (LM-test)}

The Lagrange measurement is an approach to obtain a more precise model between the random effect and the common effect before entering the interpretation stage. One of the values that identify the Lagrange test is the Breusch-Pagan value.

Table 4. The Output of the Lagrange Multiplier test.

\begin{tabular}{|l|c|c|c|}
\hline \multicolumn{1}{|c|}{ Null (no rand. effect) } & Cross-section & Period & \multirow{2}{*}{ Both } \\
\hline Alternative & One-sided & One-sided & \\
\hline Breusch-Pagan & 80.20500 & 1.519484 & 81.72449 \\
\hline & $(0.0000)$ & $(0.2177)$ & $(0.0000)$ \\
\hline Honda & 8.955725 & -1.232673 & 5.461022 \\
\hline & $(0.0000)$ & $(0.8912)$ & $(0.0000)$ \\
\hline King-Wu & 8.955725 & -1.23263 & 0.943892 \\
\hline & $(0.0000)$ & $(0.8912)$ & $(0.1726)$ \\
\hline GHM & -- & -- & 80.20500 \\
\hline & -- & -- & $(0.0000)$ \\
\hline
\end{tabular}

Table 5 explains that the p-value in Breusch-Pagan is lesser than the significance level value $(0.000<0.005)$ or the LM-test point is greater than the ChiSquare table $(80.20500>47.399)$, then $H_{o}$ is rejected. Thus, the best estimation model used in this research is the random effect model.

\subsection{Model significance test}

\subsubsection{The simultaneous criteria (F-statistic)}

The F-statistic on random effect describes that 95 percent there is variable that has a significant relationship on this model. Hence, researchers need to continue the partial test to find out the significant variable.

\subsubsection{The partial criteria (T-statistic)}

The T-statistic is a measure the effect individually on the dependent variable. This analysis explains that the land area had a relationship with rice production $(0.00<0.05)$. Meanwhile, the labor and capital explain have not a significant impact on the dependent variable. Hence, the land had a positive impact while the other two variables showed no significant effects on rice production in Indonesia. 


\subsubsection{The r-squared test}

The coefficient of determination can describe the ability of a model to explain its variations. As seen in the output of random effect, it has a determinant coefficient value of 0.9746 . It confirms that the independent which can describe the dependent variable is 97.46 percent.

\subsection{Research discussion}

\subsubsection{Land area indicator}

The results of panel analysis on the land area in this research showed that the probability value was lesser than the significance value. This number suggests that land area had a positive relationship with the growth of rice production in Indonesia. Similar to this research, Pudaka and Aprillya also conducted a study and showed that the dominant factor in encouraging rice growth is the land area [28] \& [29]. It illustrates that the increasing paddy fields will also increase rice output in Indonesia. In the projection, this growth will keep rising if the mechanism for rice harvesting is also improved.

However, to anticipate the expansion and conversion of the rice fields into industrial or property land that keeps increasing, there should be improvements and efforts. The government could take some actions, like securing rice fields and some areas designated for agriculture. They also could nationalize agricultural land for state assets, express declaration as to the state of agriculture at the federal level, arrange land protection laws and socialize various land and other agriculture policies. It is necessary since the rice fields conversion will reduce the land area in the short term impact and influence the national economic situation in the long term [30].

The rice harvested area had decreased by 0.019 percent in 2020 to 10.66 million hectares compared to 2019 that reached 10.68 million hectares. The changes in the output choice of commodities and the function-shifting in agricultural land had led to this degradation [31]. In 1984, on the other hand, the perspective that focused on agriculture as the basis of commodity growth had encouraged rice self-sufficiency in Indonesia. However, this condition only lasted temporarily due to fluctuations in rice production that happened again in the next few years [32].

IAARD also mentioned that fluctuations in rice production in Indonesia had stimulated the establishment of various work programs to increase productivity. The programs were Mass Guidance (BIMAS), Special Intensification (INSUS), SUPRAINSUS (SI), System of Rice Intensification program (SRI-program), and others [32]. In addition, the Ministry of Agriculture of the Republic of Indonesia released several policies and programs to ensure food security in the new normal or post COVID-19 era through the Four Ways of Action Strategy. The strategies related to rice availability include: 1) expansion of new crop areas for primary food production (rice and corn), as well as other commodities, such as chili and shallots, 2) strengthening of District/City Government Rice Reserves (CGRR) and Provincial Government Rice Reserves (PGRR), 3) Smart farming, and 4) Food estate development in Central Kalimantan [33]. 


\subsubsection{Labor indicator}

The labor indicator had a higher probability value than the significance value or $(0.6732>0.05)$. It indicates that labor does not have a significant effect on the growth of rice production in Indonesia. This result is not in line with Jamaludin's research which suggests that the labor availability indicator is one of the dominant indicators in rice production in Malaysia [34]. The laborers can help the government save the budget for import activities and subsidies for rice commodities.

The data from Statistics Indonesia shows that the agriculture and plantation sector is the largest employment sector seen from how many Indonesian workers aged fifteen years and over in this field. In addition, the percentage of informal workers working in the agricultural sector increased by 0.25 percent in 2020 compared to 2018 [35]. The increase in the number of workers in the agriculture sector is not in line with the existing land area [36]. Nowadays, agricultural land experiences some degradation, and land function-shifting has worsened the situation. It happens when the rice fields function as other commodities fields, too.

Agriculture is the primary sector of employment in rural areas that increases the poverty rate [37]. When a high supply of labor is not proportional to the demand for labor, the absorption will be less than optimal and causes unemployment [38]. Hence, labor is one form of investment to consider in encouraging the quality and effectiveness of human resources. However, the number of existing workers must also balance the availability of existing agricultural land.

Consequently, productivity must shift to other sectors to overcome the imbalanced number of laborers. Awaliyyah examined the structural changes in the agricultural, service, and industrial sectors in Asian countries [38]. The results showed there is a shift in labor productivity from the agriculture sector to the service sector. In addition, although the agricultural sector still occupied the largest workforce, it did not contribute to the largest GDP in Asian countries. In Indonesia, the contribution of the agriculture sector ranks second after the industrial to the state income.

\subsubsection{Farmers' capital indicator}

The farmers' capital indicator used in this research was the value of additional capital goods needed by food crop farmers from the Production Cost and Capital Goods Addition Index (PCCGA) in each province in Indonesia. This index for food crop farmers consists of the calculation of all the needs used by farmers in providing or increasing capital for production, such as the need for fertilizers and medicines, seeds, transportation, additional capital goods, wages for farm laborers, tax payments, land rent costs, and others.

The estimation result of the model showed that the effect of increasing farmers' capital on this research had a higher probability value than the significance level value $(0.2954>0.05)$, confirming that the additional funds needed by the farmers in the production did not have a significant effect on rice production in Indonesia. This finding is also similar to Pudaka's research saying that the fertilizer indicator is a factor that does not influence the level of rice production [28]. Another study conducted by Jimmy also found a negative impact on the environment in the life cycle assessment (LCA) of pesticides usage, fertilizers, and non-renewable resources in Bangladesh [39]. There should be an upgrade in green technology that 
is more beneficial to gain public trust about the products, food sustainability, furthermore encourages the use of environmentally friendly products.

In addition, Tun and Kang found that the measurement of the efficiency value of educated farmers is higher and has more potential to encourage the use of technical efficiency programs [40]. Meanwhile, farmers find it hard to adopt modern agricultural technology and prefer maintaining traditional farming practices. Farmers are also often faced with various problems with the availability of other production capital. They encounter many issues such as high prices for pest control or pesticides and rising fertilizer prices. Also, the high price for rice supply set by middlemen has increased the burden of farmers in production and crop protection [41].

\section{Conclusion}

In this research, the most appropriate model was the random effect one. The measurement for labor and farmers' capital variable did not show any crucial impact. Hence, only the land area variable explained the most significant impact on the growth rate of rice production in Indonesia. The government policy is needed to solve the agricultural land diversification, particularly the rice fields with a limited area in Indonesia. Also, the government needs several guidelines to overcome the unemployment problem in the agriculture sector and socialize the use of environmentally friendly products by farmers to realize national food sovereignty.

\section{References}

1. Statistics Indonesia, Econ. Trade 1 (2020).

2. Statistics Indonesia, Consum. Ecpenditure 1 (2019).

3. Food And Agriculture Organization Of The United Nations, 21, Issue No. 11 (2018).

4. Sustainable Development Goals (SDGs) Indonesia, (2017).

5. A. A. Sulaiman, K. Subagyono, D. Soetopo, S. Sulihanti, and S. Wulandari, Kebijakan Penyelamat Swasembada Pangan, II (IAARD Publisher, Jakarta, 2018).

6. Ministry Of Agriculture Republic Indonesia, Analisis Dinamika Konsumsi Pangan Masyarakat Indonesia (Jakarta, 2013).

7. Food Security Agency, Badan Ketahanan Pangan 1 (2020).

8. Global Food Security, Rank. Trends (2020).

9. Statistics Indonesia, Foreign Trade (2019).

10. A. A. Sulaiman, K. Subagyono, Hermanto, Suwandi, B. Sayaka, R. Kustiari, S. K. Dermoredjo, J. F. Sinuraya, P. B. K. Santoso, and F. A. Bahar, Perdagangan Internasional Komoditas Pangan Strategis, I (IAARD Publisher, Jakarta, 2018).

11. G. Bishwajit, S. Sarker, M. A. Kpoghomou, H. Gao, L. Jun, D. Yin, and S. Ghosh, Agric. Food Secur. 2, 1 (2013). 
12. A. Soltani, S. M. Alimagham, A. Nehbandani, B. Torabi, E. Zeinali, E. Zand, V. Vadez, M. P. van Loon, and M. K. van Ittersum, Glob. Food Sec. 24, 100351 (2020).

13. S. Zhan, J. Rural Stud. 54, 151 (2017).

14. N. Deng, P. Grassini, H. Yang, J. Huang, K. G. Cassman, and S. Peng, Nat. Commun. 10, 1 (2019).

15. P. A. J. Van Oort, K. Saito, A. Tanaka, E. Amovin-Assagba, L. G. J. Van Bussel, J. Van Wart, H. De Groot, M. K. Van Ittersum, K. G. Cassman, and M. C. S. Wopereis, Glob. Food Sec. 5, 39 (2015).

16. A. Arouna, I. A. Fatognon, K. Saito, and K. Futakuchi, World Dev. Perspect. 21, 100291 (2021).

17. S. Nuryanti, D. B. Hakim, H. Siregar, and M. H. Sawit, Indones. J. Agric. Sci. 18, 77 (2018).

18. T. Fristovana, M. Hubeis, and E. R. Cahyadi, J. Manaj. Dan Agribisnis 16, 121 (2020).

19. R.-M. Bălă and E.-M. Prada, Procedia Econ. Financ. 10, 141 (2014).

20. M. Firdaus, Aplikasi Ekonometrika Dengan E-Views, Stata, Dan R, First (IPB Press, Jakarta, 2020).

21. T. Hiestand, Int. Bus. Econ. Res. J. 4, 37 (2011).

22. S. Ren and T. M. Choi, Ind. Manag. Data Syst. 116, 1131 (2016).

23. K. Yunitaningtyas, A. M. Yolanda, and Indahwati, J. Phys. Conf. Ser. 1265, (2019).

24. B. H. Baltagi, Econometrics, 4th ed. (Springer-Verlag Berlin Heidelberg, New York, USA, 2005).

25. P. Clarke, C. Crawford, F. Steele, and A. Vignoles, Educ. Econ. 23, 259 (2015).

26. P. Clarke, C. Crawford, F. Steele, and A. Vignoles, IZA Discuss. Pap. 36 (2010).

27. B. H. Baltagi, Econometrics, Fourth (Springer-Verlag Berlin Heidelberg, USA, 2008).

28. D. L. Pudaka and P. E. Prasetyo, J. Econ. Educ. 7, 31 (2018).

29. M. R. Aprillya, E. Suryani, and A. Dzulkarnain, J. Inf. Syst. Eng. Bus. Intell. 5, 67 (2019).

30. M. U. Azizan and K. Hussin, J. Teknol. 78, 39 (2016).

31. A. Ramadhan, Www.Antaranews.Com (2020).

32. Indonesian Agency for Agricultural Research and Development (IAARD) Press, Pembangunan Pertanian Berbasis Ekoregion (IAARD Press, Jakarta, 2015).

33. Ministry Of Agriculture Republic Indonesia, Akd.Sb.Ipb.Ac.Id 1 (2021).

34. N. L. Jamaludin, A. Amer, and H. F. Abu Hasan, Icast 1 (2010).

35. Statistics Indonesia, Www.Bps.Go.Id 1 (2020).

36. The Global Economy, Agric. Sect. (2019). 
37. X. Qin, H. Shen, S. Ye, and L. Zhou, J. Hosp. Tour. Manag. 47, 114 (2021).

38. The Global Economy, Agric. Sect. (2019).

39. A. N. Jimmy, Model. Earth Syst. Environ. 3, 1691 (2017).

40. Y. Tun and H.-J. Kang, East Asian Econ. Rev. 19, 167 (2015).

41. M. Abdullah, L. I. Cuixia, S. Ghazanfar, A. Rehman, B. Ghazanfar, and S. Saud, J. Biol. Agric. Healthc. 3, 1 (2013). 